\title{
OM AT VENTE OG IKKE VIDE Tid og disciplin i en engelsk primary school
}

Fire elever i en engelsk primary school ${ }^{1}$ sad i børnehaveklassens indendørs sandkasse:

Garry: 'Vi kunne putte Joseph i skraldespanden'.

Joseph: 'Nej, vi kunne putte Mrs. Cook [deres klasselærer] i skraldespanden, og så kunne vi alle sammen være Mrs. Cook!' [implikation: så kunne vi allesammen være voksne]. Garry: 'Ja, og så kunne vi gøre, hvad vi ville'.

Joseph foreslog (mere ydmygt): 'Så kunne vi være fem i sandet!' [i stedet for fire, som var det maksimale tilladte antal elever ad gangen i sandkassen].

Garry: 'Vi kunne allesammen lege i sandet'.

Jessica: 'Hundrede mennesker i sandet!'

Garry: 'Vi kunne have en hel masse børn i klassen, så den var helt fyldt op med børn!' (Feltnoter, nov. 1994). ${ }^{2}$

Garry, Joseph, Jessica og Jonathan diskuterede voksendommens ${ }^{3}$ privilegium. De udtrykte klar forståelse for, hvorledes alder kan markere og afgrænse magten til ,at kunne gøre hvad man vil“. Selv var de alle fire år gamle.

I 1994-96 foretog jeg 13 måneders feltarbejde i Little Midby, en engelsk landsby i det sydlige Nottinghamshire. ${ }^{4}$ Feltarbejdet var primært centreret omkring børn i alderen 5-7 år, og jeg tilbragte store dele af min dagligdag i landsbyens primary school for børn i alderen 4-11 år. I det følgende skal jeg prøve at vise, hvorledes tid - tid som alder, tid som ressource og tid som nøje afmålte „rum“ for aktivitet - spillede en væsentlig rolle i skolen.

\section{En kort bemærkning om metode og teori}

Mit arbejde fokuserer på disciplin. Disciplin forståes traditionelt som praksiser og strategier (eller ideologier), hvis udtrykte mål er kanaliseringen af adfærd og tankegange i en bestemt retning. ${ }^{5}$ Med ,,disciplinering“ mener jeg dog også, og bredere, ,,socialisering “; det vil sige de relationer, processer og interaktioner, hvorigennem børn og voksne kontinuert forhandler, markerer og installerer hinandens identiteter. ${ }^{6}$ Min tilgang tager udgangspunkt i en kritisk læsning af de nyere børnestudier, hvor hovedvægten lægges på analyser af såkaldte „børnekulturer“ (eksempelvis James 1993; Berentzen 1989). For så 
vidt gælder den detaljerede etnografiske kortlægning af børns liv og praksis, er disse studier både nødvendige og indsigtsrige, men i en overordnet teoretisk synsvinkel skyder de så at sige forbi målet. Med et for ensidigt fokus på „,børns kultur“ isoleres børn analytisk og i teorien fra de bredere samfundsmæssige eller sociale kontekster, i hvilke børn konstrueres som sådanne. ${ }^{7}$ I et fors $\emptyset \mathrm{g}$ på en alternativ tilgang søger jeg at forstå disciplin som en dynamisk socialiseringsproces, der går ,,begge veje“. Mit overordnede mål er derfor at afdække, i den empiriske detalje og med øje for den specifikke historiske kontekst, hvorledes voksne og børn etablerer og forhandler deres subjektpositioner, eller identiteter, gennem gensidigt socialiserende, interaktive relationer.

Måske bemærkede jeg i særlig grad disciplinære praksiser på grund af den måde, jeg udførte mit feltarbejde på. Som det diskuteres detaljeret andetsteds (Lærke 1998), bestræbte jeg mig på at være så ,barne-agtig“" som muligt. Jeg klædte mig ligesom børnene, spiste med børnene, stod pænt på række med børnene og så videre. Jeg konfererede ikke dagligt med skolens personale og vidste derfor kun, hvad man som elev i skolen ville vide, hvilket generelt ikke var ret meget, hvad angik den overordnede planlægning af skoledagen. Jeg tror, at jeg fra min position nede på gulvet sammen med eleverne lagde mere mærke til skolens disciplinære teknikker, end havde jeg siddet, på afstand, på en stol som de andre voksne i skolen. Disciplinen - både børns og voksnes - så at sige rørte ved mig, og den spillede en væsentlig rolle i min egen feltsocialisering.

De mest synlige og mærkbare disciplinære teknikker i skolen omfattede: anvendelsen af tid, kontrollen med viden og hemmelighedens funktion, brugen og kategoriseringen af rummet langs en høj-lav-akse, tilretningen eller dressuren af kroppe og inspektion og eksamination af både elever og personale. Jeg skal her kun beskæftige mig med den førstnævnte, nemlig brugen af tid som disciplineringsmåde i skolen.

\section{Tid som alder}

Som også andre har pointeret (James \& Prout 1990a, 1990b), er et barns biologiske alder i den vestlige kulturelle kontekst konstrueret som værende næsten synonymt med hendes/hans hele identitet. Ikke blot betegner alder et barns kognitive og fysisk-motoriske ,udviklingstrin“; alder ses også som en generelt anvendelig parameter for børns erfaring, sociale modenhed, personlige autonomi og kropslige størrelse (,lille“ bruges ofte synonymt med ,ung“). Dette hænger blandt andet sammen med en omfattende vestlig forestilling om „,barnet“" som mere ,naturligt“, mindre „,kultiveret“ (James \& Prout 1990a; Lærke 1998). Jo yngre et barn er, des mere minutiøst karakteriseres hans/hendes alder (ned til måneder, uger, ja endda dage), medens voksendommen er relativt u-aldret indtil alderdommen, hvor kronologisk alder igen bliver signifikant (Hocey \& James 1993). Livsforløbet synes konstrueret som en optælling fra begyndelsen af livet og en nedtælling hen imod livets afslutning med voksendommen indimellem som dén eksistens, vi alle hele tiden enten stræber hen imod eller kigger længselsfuldt tilbage på. I et voksencentrisk samfund som det engelske markerer kronologisk eller biologisk alder ikke blot tidens arbejden i og for det enkelte menneskes personlighed, tiden fremstilles også som en kvalitet i sig selv, der akkumuleres over et livs forløb. ${ }^{8}$

Børnene i Midby skole var meget bevidste om hinandens alder. Deres indbyrdes hierarkier etableredes ofte i alderstermer. Således var det for eksempel altid den ældste, 
som ,startede“, når noget gik på tur. Dette var i starten temmelig forvirrende for mig. Når vi spillede et brætspil, formodede jeg, at terningen ville gå i simpel rundgang fra den ene til den næste i den orden, vi nu tilfældigvis sad i. Men nej, terningen gik på kryds og tværs og tegnede en tydelig skala af aldersbestemt autoritet og privilegium. Ligeledes var de badges, børnene bar på deres fødselsdag - ,Jeg er 5 i Dag!“ - manifestationer af alderens betydning: Børnene bar bogstaveligt talt deres alder uden på tøjet.

Den lokale konstruktion af alderens væsentlighed for et barn reflekterede den lokale konstruktion af alderens uvæsentlighed for en voksen, og vice versa. Dette begyndte at dæmre for mig på den første fødselsdag, jeg oplevede blandt skolens personale. Mrs. Rogers, skolens dinner lady (som serverede skolemåltidet), havde fødselsdag. Jeg vidste, at hun blev 50 år, fordi jeg havde underskrevet personalets kort til hende. Det var derfor med undren, jeg hørte Mr. Fisher, skoleinspektøren, i sin tale til den forsamlede skole erklære, at Mrs. Rogers blev tyve år i dag. Mr. Fisher smilede, hvad jeg formodede skulle være et charmerende smil. Senere viste det sig, at denne ,af-aldren“ af det kvindelige personale var typisk: Det var ikke blot the dinner lady, som for evigt var tyve år gammel (den yngst mulige ,voksne“ alder, kunne man sige); det var også den kvindelige sekretær, hjælpelæreren og mig selv på vore fødselsdage. Jeg skrev i mine feltnoter:

Gad vide hvad Mr. Fishers idé var med at gøre os alle tyve år gamle? Det er sikkert en eller anden form for engelsk 'gentleman-ness' som jeg ikke helt fatter. Noget i retning af, at 'man spørger ikke en dame om hendes alder'. Men det var også noget andet. Noget, som ikke var særligt 'gentle', men muligvis meget 'manly'. Jeg var faktisk forarget; jeg følte mig angrebet, på en måde. Det var som om en magt var blevet taget fra mig. Gjorde Mr. Fisher os ikke mindre autoritative, mere magtesløse eller svage, ved at trække år fra vor alder? Eller er det min egen fordom, hvad angår alder - min egen 'alder-isme' - som fik mig til at føle det sådan? Han ligesom 'mindreværdigede' os. Og jeg gad vide hvorfor det kun er kvinder, som, høfligt, bør formodes at være langt yngre end de er? (Feltnoter, jan. 1995).

Ikke blot var den voksne biologiske alder noget, man ikke burde nævne, den syntes tilmed at være kønsspecificeret. Da det var skoleinspektørens egen fødselsdag, var der ingen, der sagde noget om hans alder overhovedet, og da slet ikke at han var tyve. Måske fordi jeg ønskede at være sammen med børnene på så ,lige“ præmisser som muligt, irriterede det mig, at jeg på min 31 års fødselsdag blev præsenteret som 20-årig. Så jeg fortalte børnene, hvor gammel jeg ,rigtigt“ var. Børnene syntes fascinerede af denne afsløring, som spredte sig med en ilds hast til alle klasser. I flere dage derefter kom børn tilbage til mig for at spørge, om jeg virkelig var så gammel?

På baggrund af den generelle og vidtrækkende forestilling om livstid som en art personlighedens ressource tegnede der sig andre vigtige aspekter af den lokale brug af tid. Jeg vil her forsøge at ridse nogle af disse aspekter op, sådan som de forholder sig til disciplineringspraktikker i skolen.

\section{Administration af tid som disciplineringsstrategi}

I det mindste hvad angår magtens mere åbenlyse omgang med tiden, var det de voksne i skolen, som udøvede tidskontrol. Med tidskontrol mener jeg ikke blot kontrol over skemalægningen, men også mere fundamentalt over målingen af tid eller over midlerne til at 
„vide“ eller „,kende“ tiden (det vil sige ure). De voksne satte tidsrammerne: Der var læsetid, lyttetid, legetid, spisetid, tid til at drikke skolemælk, tid til at sidde, tid til at stå i række, tid til at løbe, tid til at vaske hænder, tid til at tale og tid til at tie stille. Opgaver kom uvægerligt med instruktioner om tid. Læreren ville sige, „I har ti minutter til at gøre dette eller hint". Denne tidsafgrænsning gjaldt altid kun den umiddelbart forestående tid - for eksempel de næste ti minutter. Hvad der lå derefter - for eksempel ,efter frikvarteret“ eller „,i morgen“ - var umarkeret og usagt. Som jeg skal vende tilbage til, resulterede dette i en manglende fornemmelse for kontinuitet og formål. Tidsdisciplineringsteknikkerne var desto mere virkningsfulde, fordi der ikke var noget synligt ur i klasseværelset. Eleverne vidste, at deres arbejde blev timet og ophugget i små, håndterlige stykker af aktivitet. Men de kunne ikke referere til et fælles ur; de kunne ikke tage deres tid i egne hænder. Nogle af børnene bar armbåndsure - nydelige lyserøde Barbie-ure eller eventyrligt monstrøse Disney-ure - men, som det generelt var forventet af mennesker i deres alder, havde de fleste endnu ikke lært klokken. Jeg så da heller ikke noget forsøg på at lære børnene klokken kollektivt og i skoletiden. At lære at bruge klokken aktivt som en administrativ teknik var ikke en del af det daglige liv i de 5-8 åriges klasseværelse.

Dog, i én ganske bestemt sammenhæng var elevernes aktive kontrol af den fælles tid fuldstændig central. Mandagmorgener havde vi ,nyhedstime“ i Mrs. Stenns klasse. Her blev børnene opfordret til at rejse sig, én for én, og fortælle om, hvad de havde lavet i løbet af weekenden, eller hvilke nye legesager, de havde erhvervet sig. Mrs. Stenn, klasselæreren, havde et timeglas. Det tog ét minut for sandet at løbe ned, og dette var den afmålte tid, hvert barn havde til at fortælle. Mrs. Stenn ville allerførst udpege en timeglaskontrollant - en åbenlyst vigtig post for børnene at få tildelt. Atmosfæren under udpegelsen var anspændt og tæt af forventning. Lige hér, i interaktionen mellem børn og voksen, blev kontrol over tidens forløb konstrueret som en magt. Timeglasvenderens råben, når tiden var udløbet, smældede af autoritet. ${ }^{10}$

Lige så åbenlyst som skoletiden var skemalagt, lige så uvidende (eller i det mindste dårligt informerede) var både jeg og børnene om den overordnede planlægning af skoledagen. Jeg forestiller mig, at eleverne brugte samme fremgangsmåde som jeg selv; det vil sige gradvist og ikke helt bevidst at sammenstykke et mentalt og kropsligt skema over skolens tid: at notere sig rutiner og deres regelmæssighed; at blive sulten, når det snart var tid til frokost; at føle sig utidig og rastløs, når frikvarteret var på vej, og at blive utålmodig og ugidelig lige når det var ved at være tid til at rydde op og gå hjem. Kort før sommerferien spurgte jeg Mrs. Stenn om planerne for efterskoleklubber i det følgende skoleår. Hun svarede, at skemaet for næste år ville være det samme som det for i år. Til min forbavselse medbragte hun den næste dag et helt igennem simpelt og klart overskueligt skema for det år, vi netop afsluttede. Så her havde vi, børnene og jeg, nøje fulgt et skema, vi ikke engang vidste eksisterede! Hvorfor, spurgte jeg mig selv (men ikke Mrs. Stenn), havde dette skema ikke været oppe på klasseværelsets væg til almen oplysning?

Som antydet var kontrollen over tiden direkte knyttet til administrationen af viden. Informationer flød ikke frit og let mellem skolens personale, elever og forældre. Jeg var ofte i vildrede over det mere overordnede formål med enkeltaktiviteter eller simpelthen over, hvorvidt for eksempel svømning i dag nu var aflyst eller ej. I lang tid tog jeg min forvildelse som tegn på mit feltarbejdes ineffektivitet, men efterhånden som ,netball-affæren" udviklede sig, blev jeg klar over, at det ikke blot var mig, men også børnene og deres forældre, som aldrig var helt klare over, hvad der foregik hvor, hvornår og hvorfor. 
Netball-klubben blev oprettet som en slags pigernes pendant til fodboldklubben, som, bortset fra en enkelt pige, udelukkende bestod af drenge. De ældste piger (de 9-11 årige) talte meget om den netball-klub: Om hvilket tøj, de ville have på, når de spillede, om hvorledes holdene skulle sammensættes, om hvilket hold, der skulle have mig med og om, hvordan man kunne arrangere sit hår, så det ikke faldt ned i øjnene, mens man spillede. Pigerne $\varnothing$ vede sig i frikvartererne og skubbede derved midlertidigt de ældre drenge væk fra deres vanlige plads i skolegårdens centrum. For Linda, tror jeg, havde netballklubben en særlig betydning. Linda var en af de ældre piger i skolen. Hun var lang og tynd og fuld af gråd; hun stod ofte alene op ad skolemuren med de blege hænder på ryggen. Hun var ikke populær. Hun så ud, som om hun altid frøs, og somme tider brændte hendes lyseblå øjne af noget, der lignede had. Linda syntes meget opsat på at tage del i netball-klubben, men hendes mor ville først ikke tillade, at hun deltog. Efter lange forhandlinger og mine mest oprigtige forsikringer fik Linda lov, på den betingelse, at jeg fulgte hende hjem bagefter. De ældste piger konkurrerede en del om min opmærksomhed, og at jeg ville følges med Linda hjem, gav hende en ny status blandt pigerne. For en kort periode syntes Linda at være inde i varmen. Mandag efter mandag samledes vi efter skoletid for at spille bold, og mandag efter mandag blev klubben aflyst. Netball-klubben materialiserede sig aldrig, og hverken pigerne, forældrene eller jeg fik nogensinde at vide hvorfor. ${ }^{11}$ Det gør ondt at tænke på, hvad dette indebar for Linda; for at følges ad hjem efter skole uden at have en ,legitim“" grund blev aldrig helt det samme for hende og mig.

Disse var nogle af de mere åbenlyse måder, hvorpå tiden var administreret af voksne i skolen. Under disse konkrete manifestationer af magtanvendelse lå en institution, som var gennemtegnet af tidslinier, sammensat i tidsblokke; en institution, som bearbejdede tiden også på mange mindre synlige, mere implicitte, måder.

\section{Kroppene, tiden og pauserne}

En sådan indirekte måde at bearbejde tiden på var Mrs. Stenns brug af pauser. Når eleverne var urolige og uopmærksomme, havde lærerinden en disciplineringsteknik, som simpelthen gik ud på at nedsænke klasseværelset i total stilhed. Med børnene siddende på gulvet i deres karakteristiske - og påkrævede - skrædderstilling ville Mrs. Stenn fra sin stol erklære: „lad os nu se, hvor musestille vi kan være“. En næsten ubærlig lang venten indtraf: Det føltes som et tomt hul i tiden, en venten, som ikke syntes at have andet formål end netop venten. Venten på, at nogen skulle sige noget; venten på at det skulle vise sig, hvad vi ventede på; venten på, at boblen af tavshed skulle briste, og tiden sætte sig i bevægelse igen.

Disse pauser var effektive. Selvom jeg kun yderst sjældent tog noter direkte foran børnene, ville jeg somme tider prøve at skrive nogle få hastige stikord, mens vi hang suspenderet i ventetiden. Det mærkelige er, at selv når jeg forsøgte at ,stå ud af“ den umiddelbare situation på gulvet, selv når jeg prøvede at „snyde“ på denne måde, så kunne jeg faktisk ikke gøre det. Jeg kunne ikke koncentrere mig om noget, fordi jeg ventede på noget andet som jeg ikke vidste, hvad var. Jeg var nødt til at lade mig selv hænge i pausen og vente, være opmærksom, ifald noget pludseligt skulle begynde at ske igen. Jeg tror, at når tiden blev brugt på denne måde, mistede børnene - og jeg selv - retningen eller formålet af syne; vi mistede fornemmelsen for sammenhæng og bevægelse. Det var som at 
være fastfrosset i en tid, hvis forløb (eller mangel på forløb) var fuldstændigt kontrolleret af Mrs. Stenn.

I gymnastiktimerne antog lærerens tidskontrol ikke overraskende en særligt kropslig dimension:

Vi havde gymnastik i skolegården. Som sædvanlig skiftede Mrs. Stenn ikke til gymnastiktøj. Det var forbandet koldt udenfor, og ungerne må have frosset i deres gummisko og tynde t-shirts. Mrs. Stenn varmede os ikke op. Hun stod bare der og råbte: 'Løb! stop! løb! stop!' Simpelthen. Hendes fødder pegede i hver sin retning, som om tæerne ville flygte; det så komisk ud, men det var vist kun mig som syntes dét. Hun råbte: 'Løb! stop!', og vi [dvs. børnene og jeg] løb og stoppede, og nogle få ukuelige råb af fryd slap ud i skolegårdens asfalterede rum. Mrs. Stenn var der prompte: 'Jeg kan høre visse personer bruge deres mund. I behøver ikke bruge jeres mund. Brug jeres ben og arme. Ikke jeres mund'. Mrs. Stenn-pause indtraf (hvilket ikke virkede synderligt godt i åben luft) og så igen: 'L $\emptyset$ b! stop!' Jeg har endnu her til aften en brændende fornemmelse i fodsålerne efter mine fødders tunge nedslag i asfalten på stop! (Feltnoter, apr. 1995).

Min krop kan stadig huske kedsomheden - ja ligefrem en slags bedøvelse - ved denne regelmæssige svingen mellem aktivitet og inaktivitet; som et stort urs monotone tiktak. Ikke blot blev det indskærpet børnene, at der var - eller i alt fald burde være - en skarp adskillelse mellem „,mund/tale“ og ,krop/bevægelse“. Det var vel heller ikke noget tilfælde, at lærerens råb imiterede et stopur? Som jeg ser det, var denne form for eksercits (og det var ikke en engangsforestilling) endnu et eksempel på disciplinens brug af tid. Hvad det drejede sig om, kunne man sige, var børnenes kropslige internalisering af tidens afbrydende funktion, af stopurets regime.

Kroppenes tidsindstilling, pauserne, de usynlige ure og forsvundne skemaer havde stor effekt i klasseværelserne. Det var nærmest, som om aktiviteterne selv, deres indhold eller formål, blev væk under vægten af deres egen timing. Når eleverne arbejdede rundt om de store lave firkantede borde, faldt deres samtaler ofte på tid: på hvornår, du var blevet færdig med din opgave; på hvem, der var en slow coach; på hvornår, det var frikvarter; på hvornår, du gik i seng i aftes; på hvor hurtigt, du kunne skrive dit navn. Det var, som om det essentielle ved en aktivitet var, hvor lang tid den tog, eller på hvilket tidspunkt, man udførte den.

Det var i situationer, hvor det $i k k e$ forholdt sig sådan - når tiden syntes uvæsentlig eller glemt - at jeg gradvist begyndte at forstå, hvordan børnene i visse situationer brugte tiden alternativt.

\section{At være „for langsom“ eller være „for hurtig“: Børns brug af tid}

Eleverne i børnehaveklassen sad en morgen og tegnede streger langs stiplede linier. For at udvikle deres motoriske koordination, forklarede Mrs. Cook - til mig, men ikke til børnene. Føjet sammen på den, ,rigtige“ måde blev linierne angiveligt til billedet af et får: et af disse buttede, kønsløse og stereotypiske idiomer, børn så ofte præsenteres for. Oliver, en mager og livlig dreng med solhvidt strithår og store øjne, kom ikke rigtigt nogen vegne langs den stiplede linie. Jeg satte mig hos ham og kiggede på hans fåre-ark. Oliver syntes langt mere interesseret i malingen, som børnene var blevet fortalt, at de kunne bruge til at farvelægge fåret med, når de havde tegnet linierne pænt. Olivers fingre var i den 
røde maling, og han viste mig, hvad han netop havde opdaget: den nye brune som kom, når han blandede rødt og grønt. Jeg forsøgte mig med den grønne, som kom ud af gult og blåt. Rød og gul bliver orange, hvid og sort bliver grå. Vi må have været opslugt af malingen, for lige pludselig var det tid til at vaske hænder og rydde op og drikke mælk og aflevere streger til Mrs. Cook. Selvfølgelig havde Oliver ikke tegnet sine streger - faktisk var hans får temmeligt ude af form. Oliver havde været ,langsom“. Det var, hvad Mrs. Cook sagde, ikke i en ukærlig tone, men alligevel: Oliver måtte tegne sine streger efter frikvarteret.

Efter denne episode med Oliver begyndte jeg at lægge mærke til, når børn var ,langsomme". Nogle børn var notorisk slow coaches - et udtryk brugt af både elever og personale og ét, jeg ikke før var stødt på. Richard var en slow coach: Det tog ham meget længere end nogen af hans klassekammerater at klæde sig om i gymnastiktimerne. Francesca var en slow coach: Hun foretrak at gå med ganske små skridt - hæl til tå - hele vejen fra skolegården ind i klasseværelset. Og så var der folk som Oliver og Debbie, som brugte en masse tid på tilsyneladende ikke at foretage sig noget. At have brugt tyve minutter på en historie med blot tre ord var, fra lærerens synspunkt, så godt som ikke at have foretaget sig noget. Naturligvis, hvis man sad der ved bordene sammen med disse slow coaches, ville man se, at i virkeligheden foretog de sig en hel del: konversationer om tv-programmer og om besøg efter skole, gættekonkurrencer om farven på klassekammeraternes underbukser og udstillinger af viskelædersamlinger (pigerne havde en masse forskellige viskelædre i forskellige former og farver, og de mest smarte var parfumerede).

Udtrykket ,slow coach“ har konnotationer. Negative konnotationer. I min ordbog gives blandt andre følgende definitioner af ordet slow:

Tagende eller krævende lang tid [...]; Tagende mere tid end nødvendigt [...]; Registrerende en tid eller hastighed under den korrekte [...]; Sløset, inaktiv [...]; Uden interesse, kedelig [...]; Mentalt sløv [...]; Sløv, stump, tykhovedet, dum [...]; Brændende uden styrke (Reader's Digest Dictionary 1987, min oversættelse).

I den voksne skolekontekst i særdeleshed var langsommelighed forbundet med ,tilbageståenhed" i kognitiv udvikling; elever, som behøvede ekstratimer var med støttelærerens egne ord slow learners (,langsomme indlærere“). „Langsommelighed“ kan imidlertid anskues i et andet og mere positivt perspektiv. Langsommelighed, som i Olivers eksperimenter med maling og farver, kunne siges at være noget, der gør forløbet af tid til en nydelse, hvorimod venten kunne siges at være noget, som gør tiden ubærlig. Langsommelighed kunne ses som en kvalitet, der giver en aktivitet fylde eller rigelighed, hvorimod venten er en slags antiaktivitet: Når man venter, er man ikke opslugt; man balancerer på kanten af noget, men kan ikke hoppe i. Når man venter, kan man ikke foretage sig andet end at vente, og man har meget lidt kontrol over ventetiden, fordi den som regel som i Mrs. Stenns pauser - er domineret af en eller anden, man venter på. ${ }^{12}$

Men ikke blot kunne langsommelighed være en nydelse, det var også en slags politisk udsagn (jeg mener endog, at det at nyde somme tider kan være en politisk handling i sig selv). Ved at være langsom kunne et barn tage kontrol over skoletiden - hun eller han kunne tvinge lareren til at vente. Det så ikke ud, som om de andre børn havde problemer med en slow coach. Dette var, tror jeg, dels fordi der kun var få aktiviteter i skolen som var virkeligt ,gruppearbejde“ (eleverne arbejdede individuelt og var derfor ikke afhængige af hinandens tid); og dels fordi det at vente på en slow coach ofte åbnede et lille fri- 
rum - et ,hul“ mellem tidsblokkene. De, som for alvor var nødt til at vente på en langsom elev, var de voksne; det usynlige tidsskema var blevet forstyrret. Straffen for langsommelighed kunne derfor også være hård. Børn som gentagne gange var langsomme med deres omklædning til gymnastik, fik fortalt, at de skulle såmænd slet ikke gøre sig umage: De kunne sætte sig i et hjørne, forholde sig roligt og kigge på, mens de andre havde gymnastik.

Elevernes uvidenhed om skolens tidsrammer var til dels baggrunden for opførsel, som personalet kaldte ,manglende koncentrationsevne“ og ,adfærdsvanskeligheder": et barns manglende evne til at fastholde opmærksomheden på én bestemt opgave. Martin var en elev med sådanne ,,adfærdsvanskeligheder". Når klassen arbejdede, ville han med regelmæssige mellemrum kigge op og ligesom „scanne“ klasseværelset. Martin stod snarere end sad ved bordet. Han forlod ofte sit arbejde for at gå over til en anden for et $\emptyset$ jeblik at engagere sig i dennes arbejde. Af disse grunde behandlede personalet ham som en ,problemmager“, ligefrem grænsende til det såkaldt „hyperaktive“. Martin var ikke „for langsom“, han var snarere ,for hurtig“. Min oplevelse af Martin var anderledes: For mig så det ud, som om han aktivt søgte at lære klasseaktiviteternes struktur at kende; det så ud, som om han overvågede alt, hvad der foregik. Måske forsøgte Martin at kortlægge klasseværelsets tid, nu da Mrs. Stenn ikke ville hænge et skema op på væggen. For Martin, syntes det, kunne der ikke være nogen nydelse i langsommeligheden og opslugtheden, for ham var et mere aktivt kendskab til klassen som et kollektiv det vigtigste. Og måske var det ønsket om kontrol - og ikke en eller anden patologisk mental tilstand som gjorde det umuligt eller uvigtigt for Martin at engagere sig i den enkelte opgaves detalje og eneståenhed.

Langsommelighed, nydelse og ,adfærdsvanskelig opførsel“" var således teknikker, hvormed børn forhandlede sig til andre (alternative, ikkevoksne) måder at bruge eller kontrollere tid på. ${ }^{13} \mathrm{De}$,,for langsomme“ trak tiden ud og skabte derved ,huller“ i den. I disse ,huller“ kunne ikke blot de „for langsomme“ selv, men også andre børn finde en anderledes tid til at foretage sig noget andet end det, læreren havde dikteret. De ,for hurtige" skabte sig overblik over tidens plan og aktiviteters struktur og udfordrede derved, på en mindre håndgribelig, men ikke mindre effektfuld måde, den autoritet, læreren ud$\emptyset$ vede som planlægger. Hvor de „for langsomme“ brød ind i tidsskemaets regime, søgte de ,for hurtige“ at indtage eller medindtage lærerens magtposition. Måske derfor var „the slow coaches“ og ,de adfærdsvanskelige“ ofte populære hos andre børn. Deres manipulation af den fælles tid demonstrerede social indsigt og adræthed.

Når jeg foreslår, at slow coaching er et eksempel på teknikker, hvormed børn kunne disciplinere - eller yde modstand mod - voksne, er det imidlertid ikke min intention analytisk at indkapsle disse forhold $\mathrm{i}$ en simpel dialektik (såsom voksen:barn, aktion:reaktion, insisteren:resisteren osv.). En nydelig opsats som denne ville reducere forskel eller anderledeshed til en simpel permanent og allerede konstitueret opposition. Den ville ikke kunne fange kompleksiteten i de gensidige forhandlinger over, hvad der i første instans overhovedet blev opfattet som ,,aktion“, ,reaktion“ og så videre. Olivers blanden farver for eksempel blev slet ikke opfattet af læreren som en handling - det var snarere konstrueret som en ikkehandling, som en ikke-foretagen-sig-noget. Det er en banal, men ikke derfor uvigtig pointe, at en handlings betydning og indflydelse, dens intention og resultat altid er afhængig af de specifikke positioner, hvorfra handlingen foretages, opleves, og forstås. Fra skoleinstitutionens synspunkt havde Oliver ikke brugt tiden til det, 
han var blevet bedt om at bruge den til, og han havde derfor i en vis forstand slet ikke brugt tiden, men snarere spildt den. For mig derimod og, tror jeg, for Oliver selv var farveeksperimentet i høj grad ,, at bruge tiden til noget“ - det var i høj grad en ,handling“ “ja ligefrem en given sig hen. Og det var, hvad enten læreren anerkendte dette eller ej, netop lærerens forestilling om Olivers ikkeaktivitet og langsommelighed, som aftegnede det rum, hvori ,langsommeligheden“ kunne blive til noget andet; det vil sige det rum, hvori tiden kunne nydes, fordi den kunne „glemmes“. Når jeg argumenterer for, at visse aspekter af børnenes administration af tid var udtryk for modstand, gør jeg således dette med en vis forsigtighed. Magt og afmagt etableres ved forhandlinger mellem alle parter, de tavse og de talende, de unge og de ældre, de små og de større (Scott 1985); magt er noget, der gøres snarere end noget, der haves (Mark Hobart, pers.komm.), og dominans og subordination er gensidigt konstituerede aspekter af historisk situerede og kulturelt relative mellemmenneskelige forhold (Foucault 1980; Strathern 1988).

\section{Tiden som ressource}

På det individuelle såvel som institutionelle plan spillede administrationen af tid en væsentlig rolle i den strategiske, kontinuerte og gensidige lokalisering og konstruktion af identiteter eller, om man vil, af positioner, hvorfra personer kunne hævde deres selv. Iværksættelsen eller administrationen af tid var et vigtigt element i disciplinen, i socialiseringsprocesserne eller i personernes tilbliven. Man kunne i denne sammenhæng sige, at tid var konstrueret som en ressource på to forskellige måder.

Tiden blev brugt som et redskab eller en ressource i skolens og hjemmenes disciplinære og disciplinerende relationer. I skolens specifikke kontekst gav dette sig udtryk i en disciplin, hvor belønning og afstraffelse ofte bestod i en given eller tagen tid. Som jeg har fors $\emptyset \mathrm{gt}$ at vise, foregik der mellem børn og voksne en slags gensidig og mere eller mindre bevidst strategisk, kolonialisering af hinandens tid.

På et mere generelt normativt plan syntes tid også konstrueret som et medium for artikulationen af relative identiteter. Tid fungerede, ikke ulig penge, som en metaværdi: som den værdi, i hvis termer andre værdier etableredes. Både barndommen og voksendommen konstrueredes med primær reference til tid som alder. At være voksen var at undslippe tidens inskription på kroppen, erfaringen og den sociale status (og, som omtalt, var det at være mandlig voksen at undslippe sig alderen mest succesfuldt). At være barn var at underlagge sig tidens inskription på kroppen, erfaringen og den sociale status. Ydermere, i den lokale udviklingspsykologiske diskurs blev levet tid - eller erfaring - en ressource, som børn i deres relationer til voksne aldrig kunne have nok af. Man kunne sige, at den aldersdifferentiering, som lå til grund for børns interne hierarkiseringer, var irrelevant $\mathrm{i}$ barn-voksen-relationer: Voksne havde autoritet, netop fordi alderen ikke længere var nøglen til ,hvem de var“. I Little Midbys voksne, institutionaliserede og typisk evolutionistiske tilgang til børn som ,ufuldstændige voksne“ blev socialiseringsprocessen en art naturnødvendig tidens ,,arbejden på“ børns personligheder. Erfaring var således, og ikke overraskende, en ressource, som børn kun i meget begrænset omfang havde adgang til. Ligesom selvfølgelig penge var det. 


\section{Noter}

1. Hvad der svarer til den danske Folkeskole er i England opdelt (med regionale variationer) i Primary School (4-10/11 år) og Secondary School (11-16 år).

2. Direkte tale er markeret med enkelte anførselstegn for at antyde, at citater blev noteret efter hukommelsen, så snart dette var mig muligt. Båndoptagelser var sjældent mulige. Ligeledes bør det bemærkes, at alle feltnoter er oversat fra engelsk.

3. Jeg bruger den måske lidt fortænkte term „,voksendom“, snarere end „voksenalder“ eller „,voksenhed“, fordi jeg mener, at den ligesom termerne „,barndom“ $\mathrm{og}$,,alderdom“ klarest indikerer forestillingen om en aldersgruppes institutionalisering.

4. Finansiel støtte fra følgende fonde muliggjorde mit feltarbejde: Forsker Akademiet, Statens Humanistiske Forskningsråd, Knud Højgaards Fond og University of London Central Research Fund.

5. I hvilken udstrækning disciplinering udspringer af bevidste intentioner om at ,kontrollere“ adfærd, er et større spørgsmål, som jeg ikke kan gå ind i her. En fyldigere teoretisk diskussion af subjektivitet, agency, intention og autoritet kan findes i Lærke (1994).

6. Jeg bruger her termen, identitet “ med henvisning til den identitetsdebat som har været ført af blandt andre Kondo (1990), Strathern (1988, 1994), Henriques et al. (1984) og Braidotti (1994).

7. James, Jenks og Prouts nye bog, Theorizing Childhood (1998), kunne eventuelt læses som en tilsvarende kritik af børnekulturanalysen. Jeg mener dog ikke, at James, Jenks og Prout driver deres kritik langt nok. Meget kortfattet kan det siges, at forfatterne med deres Geertz-inspirerede forestilling om børns sociale verden som et privilegeret sted for „kulturens reproduktion“ kommer til analytisk at udskille børn som reproducenter af en kultur, som altid allerede er, hvorved argumentationen om børn som aktive sociale agenter med indflydelse på den falles kultur synes udhulet (James, Jenks \& Prout 1998:82-3; Geertz 1973). For en yderligere afklaring af mit eget teoretiske bagland, se Lærke (1994).

8. Og, som James \& Hockey (1993) har vist, når mennesker i den anden ende af ,,skalaen“, de gamle, ikke anses for at være manifestationer af modenhedens fuldbyrdelse, hænger det sammen med en infantilisering af alderdommen.

9. Jeg bibeholder her den lokale term „,dinner lady“, idet den har særlige klasse- og kønsmæssige overtoner, som kun nødigt lader sig oversætte - lidt på linie med det danske fænomen „,rengøringskone“.

10. Desuden var timeglasvenderen, læreren og nyhedsfortælleren de eneste i rummet, som ikke sad på gulvet. For en lidt mere udførlig beskrivelse af rummets hierarki, se Lærke (1998).

11. Det er min opfattelse, at et klasseelement gjorde sig gældende her. Deltagelse i netball-klubben var gratis, og de piger, der tilmeldte sig, var typisk børn af mindrebemidlede forældre, som ikke havde råd til at sende deres døtre til fransk, ridning, svømning, ballet og musik, sådan som de mere velhavende forældre gjorde i hæsblæsende grad. Netball-pigernes forældre var tilmed typisk de kortere uddannede (landarbejdere, fabriksarbejdere, ufaglærte arbejdsløse, servicearbejdere) blandt skolens forældre, og måske af den grund var de også langt mindre krævende, konfronterende og kritiske over for skolens lærere. Netball-mødrene beklagede sig - til hinanden og til mig - over den mangel på respekt og troværdighed, skolens personale udviste i denne sammenhæng, men, så vidt jeg er orienteret, nåede ikke én eneste forespørgsel eller endsige klage frem til de ansvarlige lærere.

12. Det er blevet mig påpeget, at denne oplevelse - og anskuelse - af „venten“ er min og ikke nødvendigvis børnenes, og at eleverne ikke nødvendigvis forblev i denne „,venten“, men måske distancerede sig fra ventepositionen via mentale ekskursioner andre steder hen. I respons til dette finder jeg det vigtigt at fremhæve for det første, at al etnografisk beskrivelse og senere analyse udspringer af etnografens egen oplevelse (se Larke (1998) for en detaljeret redegørelse for dette synspunkt), og for det andet, at min analyse hviler på observationer over en lang periode af elevers og læreres opførsel i sådanne ventesituationer. Det bemærkelsesværdige var, at eleverne generelt syntes ,parate " til at reagere på de spørgsmål og initiativer, som pludseligt ville afbryde ventetiden (uvist hvornår). Pointen er, at for ikke at blive „,fanget“ i dagdrømmeri, var eleverne nødt til ikke at foretage sig andet end at vente.

13. Tilsvarende forhandlinger foregik også uden for skolen. For eksempel forhandlede pigerne dagligt $\mathrm{i}$ skolen om hvem, der skulle besøge hvem efter skole, eller hvem der skulle sove hos hvem i weekenden. Jeg antog, at dette var pigernes daglige opdatering af, hvem der var tættere på hvem, af hvem der var ,inde“, og hvem 
der var „ude“. Når jeg talte med mødrene (og det var uvægerligt mødre), når de kom for at hente deres børn, kom en anden side af disse efterskolearrangementer imidlertid til syne. Mødrene beklagede sig over, at deres døtres indbyrdes efterskolearrangementer brød ind i mødrenes og andre søskendes planer. Ligeledes syntes de regelmæssige diskussioner om børns sengetider at afstikke en arena for barn-voksen-forhandlinger om, hvorledes hjemmetiden skulle bruges, og hvem der kontrollerede den.

\section{Litteratur}

Berentzen, S. (red.)

1989 Ethnographic Approaches to Children's Worlds and Peer Cultures. Report No. 15.

Trondheim, Norway: The Norwegian Centre for Child Research.

Braidotti, R.

1994 Nomadic Subjects. Embodiment and Sexual Difference in Contemporary Feminist Theory. New York: Columbia U.P.

Foucault, M.

1980 Power/Knowledge. Selected Interviews \& Other Writings 1972-1977.

Redigeret af C. Gordon. New York: Pantheon Books.

Henriques, J. et al.

1984 Changing the Subject. Psychology, Social Regulation and Subjectivity.

London and New York: Methuen.

Hockey, J. \& A. James

$1993 \quad$ Growing Up and Growing Old. Ageing and Dependency in the Life Course.

London: Sage Publications.

James, A.

1993 Childhood Identities: Self and Social Relationships in the Experience of the Child.

Edinburgh: Edinburgh University Press.

James, A. \& A. Prout

1990a A New Paradigm for the Sociology of Childhood? Provenance, Promise and Problems.

I: A. James \& A. Prout (red.): Constructing and Reconstructing Childhood. Contemporary Issues in the Sociological Study of Childhood. London: The Falmer Press.

1990b Re-Presenting Childhood: Time and Transition in the Study of Childhood.

I: A. James \& A. Prout (red.): Constructing and Reconstructing Childhood. Contemporary Issues in the Sociological Study of Childhood. London: The Falmer Press.

James, A., C. Jenks \& A. Prout

1998 Theorizing Childhood. Cambridge: Polity Press.

Kondo, D.

1990

Crafting Selves: Power, Gender and the Discourse of Identity in a Japanese Workplace.

Chicago: University of Chicago Press.

Lærke, A.

1994

How Do Persons Become?: Approaching Child-Adult Interaction in an English Village. Upubliceret forskningsrapport, Department of Anthropology, SOAS, University of London.

1998 By Means of Re-Membering: Notes from a Fieldwork with English Children. Anthropology Today 14(1):3-7.

Scott, J. C.

1985 Weapons of the Weak. Everyday Forms of Peasant Resistance.

New Haven and London: Yale University Press.

Strathern, M

1988

The Gender of the Gift. Berkeley, Los Angeles, London: University of California Press.

1994

Disembodied Choice. Upubliceret paper på „UCL-Goldsmith’s inter-departmental seminar“. Oprindeligt præsenteret på „The Cultural Analysis of Intentionality: Explorations in the Understanding of Other Minds“, School of American Research, Santa Fe, November 1990. 
